\title{
Üç Noktalı Eğilme Altındaki Betonarme Kirişlerde Karbon Lifli Polimerin Etkin ve Ekonomik Kullanımı
}

\author{
H. Orhun Köksal ${ }^{1}$, Ferruh Altınsoy ${ }^{2}$, Selen $_{\text {Aktan }^{1 *}}{ }^{*}$ Şebnem Karahan ${ }^{2}$, Rahman Çankaya $^{2}$ \\ 1 Department of Civil Engineering, Engineering Faculty, Çanakkale Onsekiz Mart University, Çanakkale, Turkey \\ 2 Department of Construction, Çanakkale Onsekiz Mart University, Çanakkale, Turkey \\ 03.07.2017 Geliş/Received, 24.08.2017 Kabul/Accepted
}

\section{Özet}

Lifli polimer kumaşlar betonarme kirişlerin eğilme performanslarını iyileştirmek için oldukça yaygın olarak kullanılmaktadır. Bu çalışma, karbon lifli polimer ile dıştan sargılanmış 7 adet betonarme kiriş üzerinde yapılan üç noktalı eğilme deneyi sonuçlarını içermektedir. 150x250x1500 mm boyutlarındaki deneysel kirişlerin üretilmesi için farklı basınç dayanımı değerine sahip iki adet beton karışımı hazırlanmıştır. İlk gruptaki 4 adet kiriş, ortalama basınç day animi değeri 25,7 MPa olan beton karışımı ile hazırlanırken, diğer gruptaki 3 adet kiriş ise, ülkemizde 199011 yıllardan önce yapılan betonarme binalarda görülmesi beklenen düşük basınç dayanımını yansıtması amacıyla $6,8 \mathrm{MPa}$ değerindeki beton karışımı ile hazırlanmıştır. Betonarme kirişlerin lifli polimer kumaşlar ile güçlendirilmesinde 3 farklı yöntem kullanılmıştır: 1) Yalnızca kirişin alt yüzeyi; 2) Kirişin alt yüzeyi ile birlikte pas payını ve çekme donatılarını içine alan $50 \mathrm{~mm}$ yüksekliğinde yan yüzeyleri; ve 3) U şeklinde sargılama. Deneyler sonucunda güçlendirilmiş kirişlerin göçme mekanizmaları ve eğilme davranışları, farklı güçlendirme yöntemlerinin etkileri göz önüne alınarak değerlendirilmiştir. Sonuçlar ACI 440.2R-08 Amerikan Beton Enstitüsünün Lifli Polimer Sistemleri ile Güçlendirme yönetmeliğindeki öneriler ile karşılaştırılmıştır. Lifli polimer malzeme ile beton arasındaki aderansın kusursuz olduğu varsayımının geçerliliği ile lifli polimer kumaşların çekme birim şekil değiştirme sınırları da bu çalışmada incelenmiştir.

Anahtar Kelimeler: lifli polimer, güçlendirme yöntemleri, betonarme kirişler, üç noktalı eğilme, sıyrılma

\section{Efficient Use of Carbon Fiber Reinforced Polymer for Reinforced Concrete Beams in Three-Point Bending}

\begin{abstract}
Externally bonded fiber reinforced polymer (FRP) sheets are highly popular for reinforced concrete (RC) beams to improve their flexural performance. This paper presents the results of three-point bending tests on seven RC beams externally reinforced with carbon fiber reinforced polymers (CFRP) sheets. Two concrete mixes with different compressive strength values are prepared for the production of experimental beams (150x250x1500 mm). First four

*Sorumlu Yazar (Corresponding Author): Selen Aktan

(e-posta: saktan@comu.edu.tr)

This work was supported by Çanakkale Onsekiz Mart University The Scientific Research Coordination Unit, Project Number: FBA-2014-185.
\end{abstract}


beams have been casted with concrete having mean compressive strengths of $25.7 \mathrm{MPa}$ and the other three beams are made of concrete having a very low compressive strength of 6.8 $\mathrm{MPa}$ which fall within the expected range for RC buildings constructed before 1990s in Turkey. Three different strengthening schemes are used by bonding of FRP sheets 1) only to bottom surface of the beam; 2) to bottom surface and lateral side's surfaces of $50 \mathrm{~mm}$ height including the tensile reinforcement and the concrete cover; and 3) in U-wrapping. Failure mechanisms and flexural behavior of the strengthened beams are evaluated on the basis of the effectiveness of different wrapping schemes. The results are compared with the recommendations of international code ACI 440.2R-08. The validity of perfect bond assumption of FRP-concrete interface and the tensile strain limits for FRP sheets are also examined.

Keywords: fiber reinforced polymer, strengthening schemes, reinforced concrete beams, three-point bending, debonding failure

\section{Introduction}

Modern materials and new techniques in use for strengthening and repair of existing deficient reinforced concrete (RC) structures have been still developing to obtain better performance especially during earthquakes. The use of fiber reinforced polymers (FRP) is one of the most suitable techniques for strengthening or retrofitting for existing $\mathrm{RC}$ beams for the enhancement of their shear and flexural capacities. The overall behavior of strengthened RC beams is generally predictable except debonding failure modes which causes retrofitted beams to fail at lower load levels than their theoretical strength.

Based on their extensive experimental and analytical studies, researchers (Campione and Mangiavillano 2008, Badawi and Soudki 2009, Barros et al. 2011, Mostofinejad and Kashani 2013, Baggio et al. 2014, Fayyadh and Razak 2014) highlight the fact that the strength and the ductility of RC beams enhanced at some point using FRP composites. However, the determination of the ultimate load carrying capacities and deflection characteristics of RC members strengthened by FRP composites and the description of their failure mechanisms are still under discussion. Some of these studies indicate that debonding of FRP sheets from concrete is the most common failure mode of strengthened RC beams. Debonding failure modes of flexural FRP-strengthened RC beams are classified into four categories without plate end anchorage (Gunes 2004): (a) FRP debonding from plate end, (b) FRP debonding from flexural crack, (c) FRP debonding from flexure-shear crack, (d) shear failure with concrete cover debonding. The local debonding of FRP-concrete interface occurs at flexureshear or flexural cracks when high interfacial shear and normal stresses exceed the concrete strength (Mitolidis et al. 2012, Neagoe 2012, Mostofinejad and Kashani 2013, Baggio et al. 2014, Li et al. 2014). Teng and Chen (2007) indicate that considerable uncertainty still exists with both the realistic description of the failure mechanisms and the prediction of ultimate load carrying capacity of strengthened beams. They consider the FRP debonding from plate end with or without concrete cover separation. Büyüköztürk and Yu (2006) indicate that debonding in the FRP-to-concrete adhesive interface may cause a significant reduction in the ultimate load capacity of RC beams if compared to the values obtained when perfect bond is assumed. The debonding mechanisms result in the weakening of the bond at the FRP-toconcrete interface and the composite action is gradually lost. The flexural resistance is increasingly contributed by FRP sheets during the crack growth (Baggio 2013). As a consequence, premature failure of FRP can occur since greater strain values in FRP when FRP material arrests crack opening. Ye et al. (2005) point out that debonding failure must be carefully considered in design. Their study summarize relevant specifications adopts for 
debonding failures in the new Chinese Standard for FRP in Civil Engineering. Li et al. (2013) indicate that intermediate crack induced debonding is the most common failure mode in flexurally FRP strengthened RC beams and most proposed models limit the allowable the tensile strain in FRP laminates to mitigate debonding failure. For this purpose, they investigate debonding initiation and tensile strain development of FRP laminates during debonding. They finally reach the result that the FRP laminates of most tested beams were debonded before reaching the proposed allowable tensile strength recommended by prevalent code provisions and models. Aram et al. (2008) describe different types of debonding failure modes and make a comparison between the results obtained from experimental studies and current codes relations such as ACI 318-11, fib, ISIS, JSCE, SIA166, TR55. Researchers find that there is a significant discrepancy up to $250 \%$ between different codes and guidelines for predicting the debonding loads. Furthermore, they recommend a strain limitation of $0.8 \%$ to prevent debonding at flexural cracks. Kim (2014) presents an analytical model to study the moment shear interaction of RC beams strengthened with externally bonded and near surface mounted CFRP composites and the model is evaluated including the applicability of the ACI 318-11, fib, ISIS, JSCE, SIA166, TR55 and ACI 440.2R-08 shear resistance expression. Nigro et al. (2008) evaluate the influence of cyclic external actions on the bonding behavior of CFRP sheets and plates reinforcements.

The effects of debonding failure modes on the ultimate load of RC beams externally reinforced with FRP sheets are still in debate. In order to reduce the probability of debonding failures, an efficient wrapping scheme for strengthened beams is proposed in this experimental study. The objective of the experimental study is to examine the efficiency of three different wrapping schemes by bonding of FRP sheets 1) only to bottom surface; 2) to bottom surface and in addition to sides surfaces of $50 \mathrm{~mm}$ height to the tensile reinforcement including the concrete cover; and 3) in U-wrapping. For this purpose, four RC beams have been casted with concrete having mean compressive strengths of $25.7 \mathrm{MPa}$. Since compressive strength of some RC buildings constructed before 1990s is frequently measured lower than $10 \mathrm{MPa}$ in Turkey, the other three beams are made of concrete having compressive strengths of $6.8 \mathrm{MPa}$. Furthermore, experimental findings of three-point bending tests are used for the evaluation of the debonding failure loads obtained from the theoretical approaches and code recommendations of ACI 440.2R-08.

\section{Experimental Program}

As for the practical and economical aspects of FRP retrofitting of RC beams, an experimental research program has been initiated to evaluate the influence of different wrapping schemes on the flexural strengthening at the Construction Materials Testing Laboratory in Çanakkale Onsekiz Mart University. Seven RC beam specimens has been tested under three-point bending to assess the effectiveness of three different wrapping schemes. The test specimens consist of two unstrengthened beams (Control beam: CB), two beams externally reinforced with one layer of CFRP sheet on bottom surface of the tensile zone (SB1), two beams strengthened by bonding of CFRP sheet to bottom surface and to lateral side's surfaces of 50 $\mathrm{mm}$ height to the tensile reinforcement including the concrete cover (SB2), and a strengthened beam with CFRP U-wrapping (SB3). 

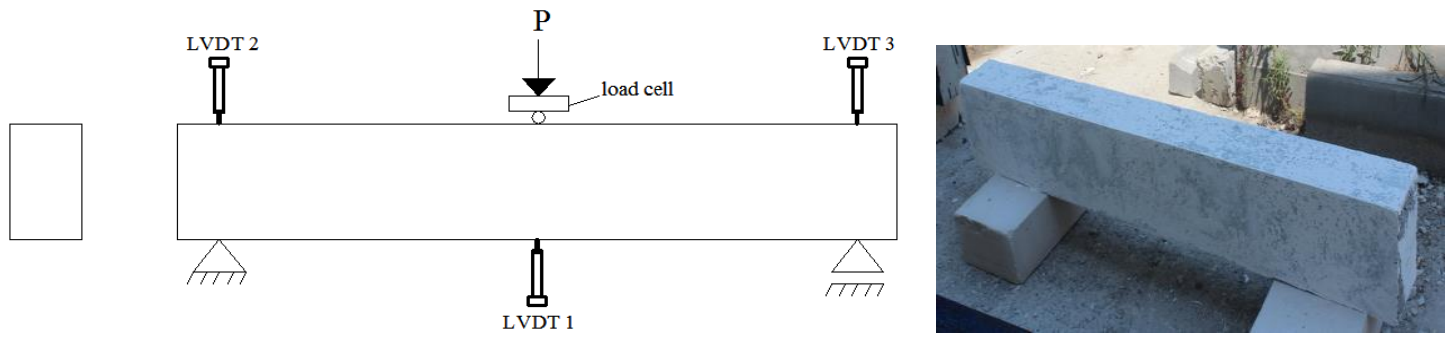

(a)
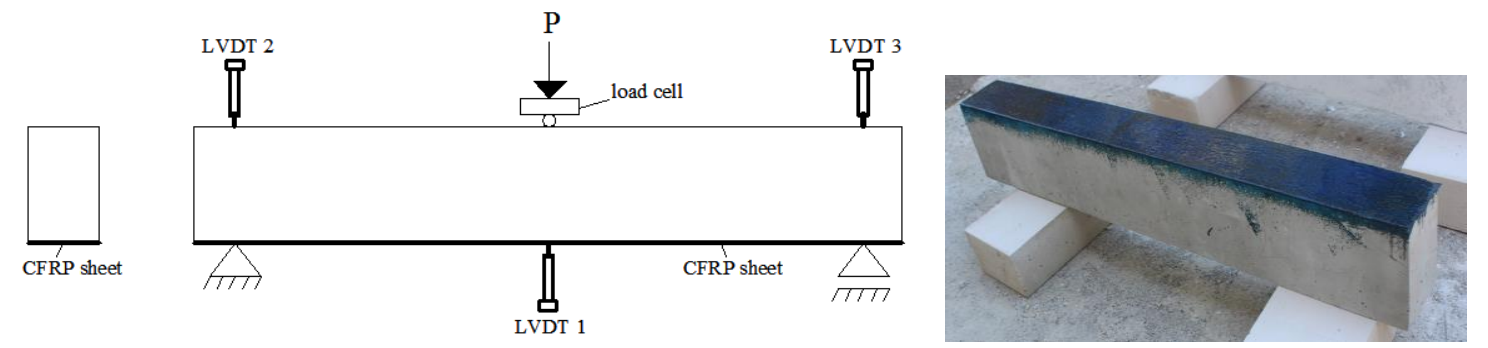

(b)

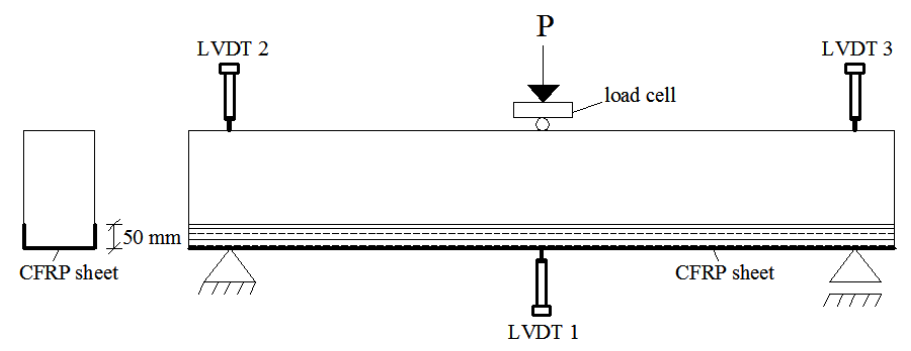

(c)
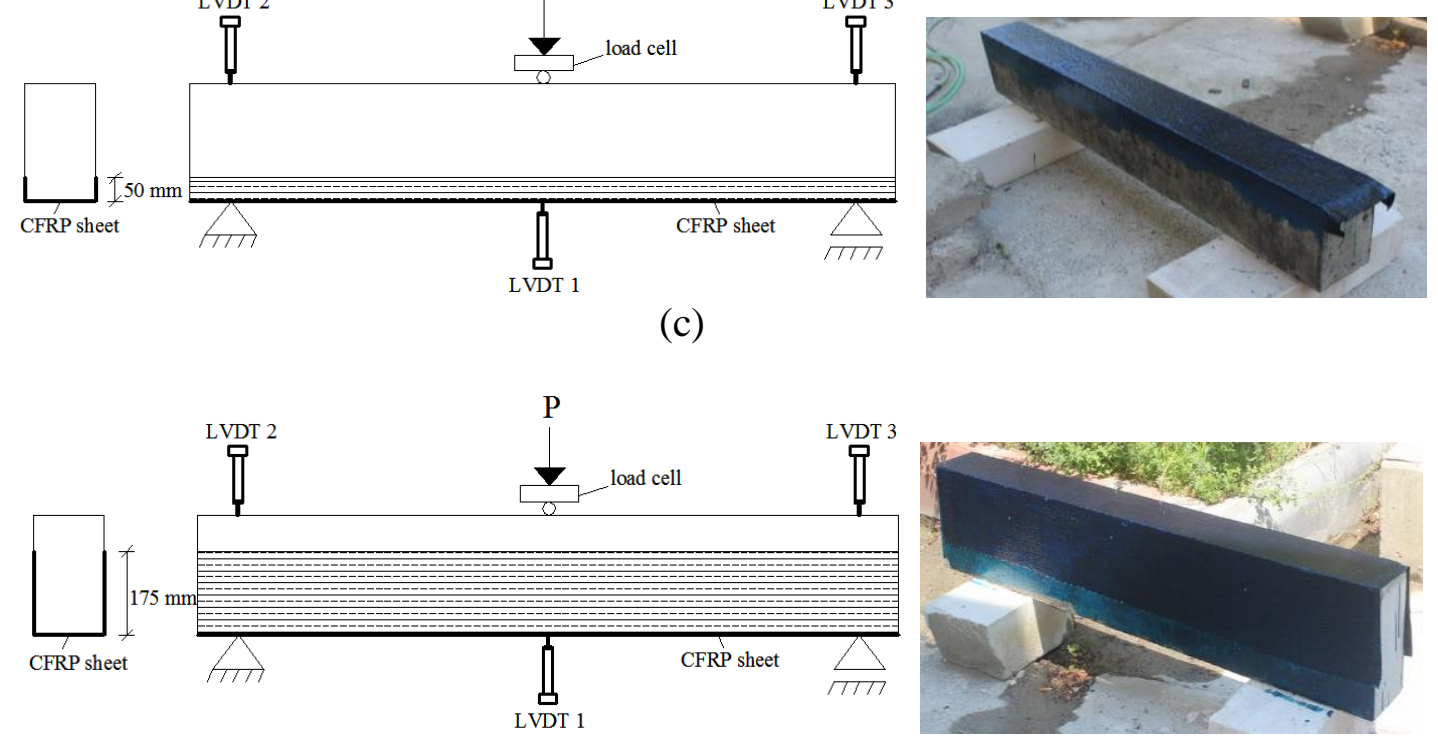

(d)

Fig. 1 Typical details of beams tested with the strengthening arrangement: (a) control beam (CB), strengthened beams (b) SB1, (c) SB2 and (d) SB3.

Debonding is initiated by the crack propagation in the vicinity of the bond interface under the tensile reinforcement. There are five possible fracture zones: 1) concrete cover, 2) concrete/adhesive interface, 3) adhesive layer, 4) adhesive/FRP interface, 5) FRP sheet (ACI440.2R-08). Therefore, an efficient wrapping scheme is proposed to reduce amounts of debonding and cracking bonding of CFRP sheets to all these possible fracture zones as illustrated in Fig. 1 (c). The Fig. 1 shows all RC beams to investigate flexural behavior of: 1SB1 and 2-SB1 beams with CFRP sheet on bottom surface, 1-SB2 and 2-SB2 beams strengthened with bonding of CFRP sheet to bottom surface and to lateral side's surfaces of $50 \mathrm{~mm}$ height. 1-SB3 beam strengthened with CFRP U-wrapping and finally control beams (1-CB and 2-CB) without retrofitting. 


\subsection{Mechanical Properties of Materials and Beam Geometry}

The beam specimens were $1300 \mathrm{~mm}$ long with a rectangular cross section of $150 \times 250 \mathrm{~mm}^{2}$. Shear reinforcement consisted of $8 \mathrm{~mm}$ diameter stirrups placed at $100 \mathrm{~mm}$ spacing. Two 12mm-diameter steel bars were provided as tension and compression reinforcement for the first series of beams. Ten mm deformed bars were placed in the tension and compression zones of second series of beams. Grade S420 reinforcing steel bars with mean yield strengths of 517.5 MPa for $12 \mathrm{~mm}$ longitudinal bars, $612.1 \mathrm{MPa}$ for $10 \mathrm{~mm}$ flexural reinforcement and 679.8 MPa for $8 \mathrm{~mm}$ stirrups were used for longitudinal and transverse reinforcement. The Fig. 1 shows the loading set-up, cross section of the tested specimens and the reinforcement arrangements. Material properties of concrete, steel and FRP sheets are summarized in Table 1.

Table 1 Material properties

\begin{tabular}{rrr}
\hline Material & Properties & Value \\
\hline Concrete (first series of beams) & Mean Compressive strength & $25.7 \mathrm{MPa}$ \\
Concrete (second series of beams) & Mean Compressive strength & $6.8 \mathrm{MPa}$ \\
Reinforcing steel & Mean Yield strength $(\phi 12)$ & $517.47 \mathrm{MPa}$ \\
& Mean Yield strength $(\phi 10)$ & $612.07 \mathrm{MPa}$ \\
& Mean Yield strength $(\phi 8)$ & $679.83 \mathrm{MPa}$ \\
& Modulus of Elasticity & $200000 \mathrm{MPa}$ \\
& & \\
CFRP sheet & Thickness & $0.18 \mathrm{~mm}$ \\
& Modulus of Elasticity & $230000 \mathrm{MPa}$ \\
& Tensile strength & $4900 \mathrm{MPa}$ \\
& Weight & $300 \mathrm{gr} / \mathrm{m}^{2}$ \\
\hline
\end{tabular}

All strengthened RC beams were wrapped with $0.18 \mathrm{~mm}$ thick unidirectional CFRP sheets in different arrangements. Beam surfaces were first rubbed and cleaned from the dust, then one layer of primer was applied to obtain a smooth surface. The primer which has a low viscosity, $100 \%$ solids, two component polyamine was used (Table 3). Then, one layer of epoxy adhesive which has a high strength, two components (epoxy resin and hardener), easily applied, epoxy based adhesive was used (Table 4). The CFRP sheet was carefully applied to the surface of the beam. One more layer of epoxy adhesive was applied on the CFRP sheet to provide a perfect bond (Fig. 2).

Table 3 Technical properties of the primer

\begin{tabular}{rrrr}
\hline Compressive properties & Value & Flexural properties & Value \\
\hline Yield strength & $26.2 \mathrm{MPa}$ & Yield strength & $24.1 \mathrm{MPa}$ \\
Elastic modulus & $670 \mathrm{MPa}$ & Elastic modulus & $595 \mathrm{MPa}$ \\
Ultimate strength & $28.3 \mathrm{MPa}$ & Ultimate strength & $24.1 \mathrm{MPa}$ \\
Rupture strain & $10 \%$ & Rupture strain & large deformation with no rupture \\
\hline Tensile properties & Value & Physical properties & Value \\
\hline Yield strength & $14.5 \mathrm{MPa}$ & Installed thickness & $0.075 \mathrm{~mm}$ \\
Elastic modulus & $717 \mathrm{MPa}$ & & \\
Ultimate strength & $17.2 \mathrm{MPa}$ & & \\
Rupture strain & $40 \%$ & & \\
\hline
\end{tabular}

Table 4 Technical properties of the epoxy adhesive

\begin{tabular}{rr}
\hline Property & Value \\
\hline viscosity & $1500-2500 \mathrm{mPa} . \mathrm{s}$ \\
compressive strength (7 days) & $>60 \mathrm{~N} / \mathrm{mm}^{2}$ \\
flexural strength (7 days) & $>50 \mathrm{~N} / \mathrm{mm}^{2}$ \\
bond strength -to concrete (7 days) & $>3 \mathrm{~N} / \mathrm{mm}^{2}$ \\
\hline
\end{tabular}



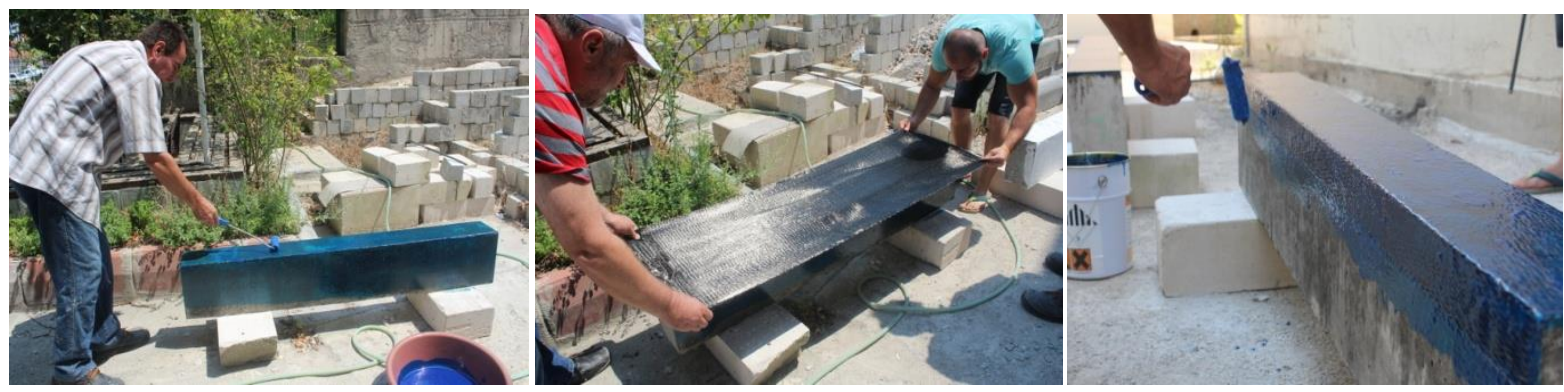

Fig. 2 The application of CPRP sheet

\subsection{Loading Set-up}

A total of seven rectangular beam specimens are simply supported over a clear span of 1300 $\mathrm{mm}$ and tested under three-point bending (Fig. 3). The load was applied using hydraulic actuator of $200 \mathrm{kN}$ capacity with a constant loading rate of $0.05 \mathrm{MPa} / \mathrm{s}$. Three linear variable differential transformers (LVDTs) were placed as shown in Fig. 1. The experimental test setup and the flexural failure of unstrengthened $\mathrm{RC}$ beam are presented in Fig. 4.

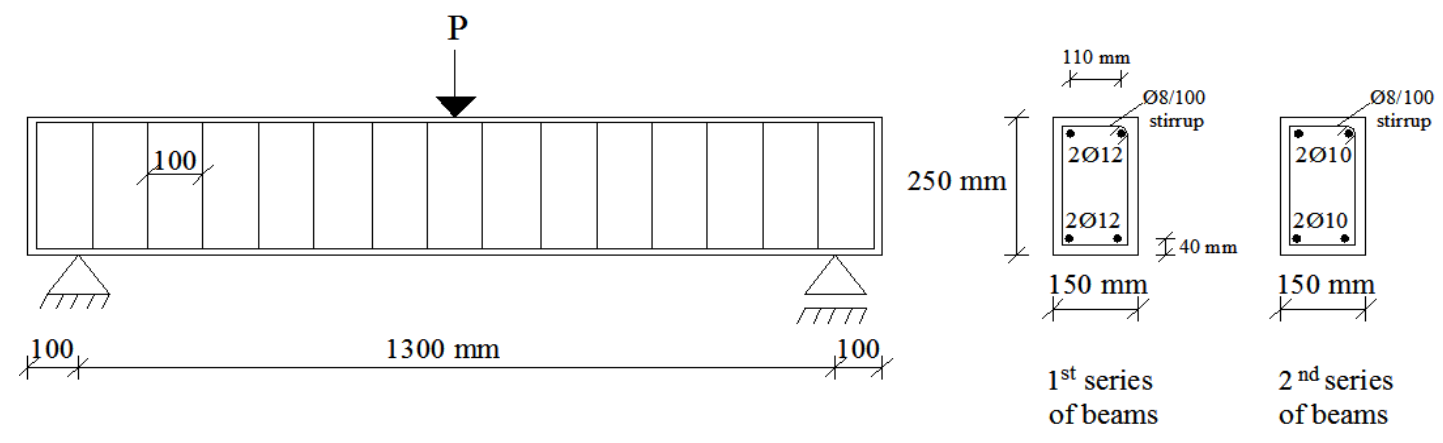

Fig. 3 Geometry and steel reinforcement arrangement of test beam

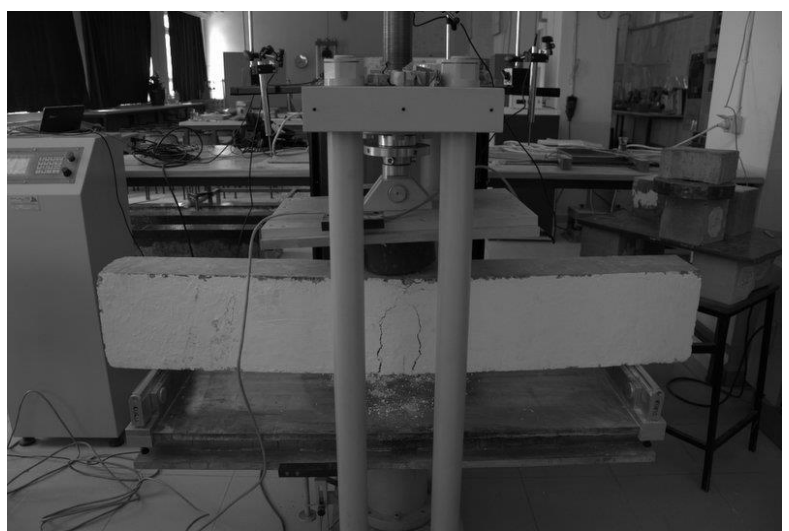

Fig. 4 Experimental set-up and flexural failure of control beam (1-CB)

\section{Summary of Observed Behavior and Discussion}

There are two major failure modes observed for the experimental beams externally reinforced with CFRP sheets, i.e. debonding of CFRP sheets from the RC beams or flexural failure of the critical mid-span section of RC beams. Debonding of CFRP sheets is in two different forms: 1) intermediate (shear and/or flexural) crack induced debonding and 2) plate end debonding as can be seen in Fig. 5. The primary aim of this experimental study is to delay crack induced debonding using the proposed wrapping scheme involving the concrete cover. 


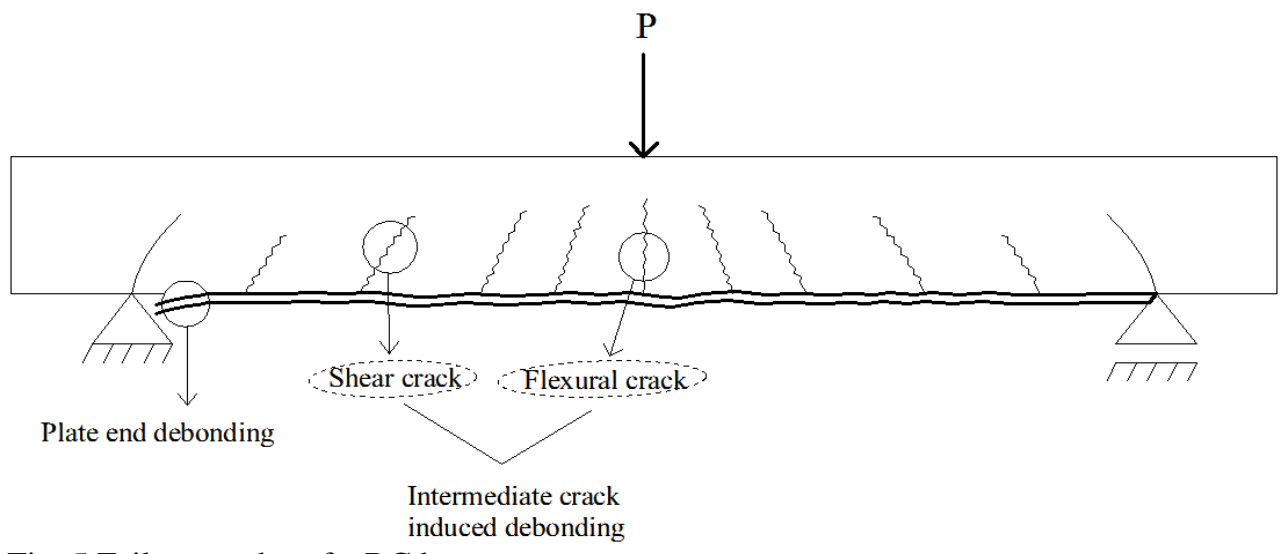

Fig. 5 Failure modes of a RC beam

\subsection{First Series of Beams (1-CB, 1-SB1, 1-SB2, 1-SB3)}

The first concrete mix (Table 2) was designed to give normal compressive strength (25.7 $\mathrm{MPa}$ ). This concrete mix has been commonly used in residential construction in Turkey. Four beams for the first concrete mix have been loaded up to failure. Their experimental and ultimate loads and corresponding mid-span deflections are summarized in Table 5. The characteristic failure modes for the first series of beams are presented in Fig. 6. The failure mode of the control beam (1-CB) is a typical bending failure at the critical mid-span section as shown in Fig. 6a. Control beam fails at an ultimate load of $46.5 \mathrm{kN}$ with a mid-span deflection of $21.29 \mathrm{~mm}$ as can be seen in Table 5. First crack was monitored at the load level of $40 \mathrm{kN}$. Large crack widths and deflections were finally observed for the main flexural cracks located under the loading point. In Fig. 7, a long yield plateau can be observed on the load-deflection diagram of the 1-CB reaching its full flexural capacity.

Table 2 Concrete mix proportions

\begin{tabular}{lccccc}
\hline $\begin{array}{c}\text { Concrete mix } \\
\text { design }\end{array}$ & $\begin{array}{c}\text { Water to } \\
\text { cement ratio }\end{array}$ & $\begin{array}{c}\text { Cement } \\
(\mathbf{k g})\end{array}$ & $\begin{array}{c}\text { Water } \\
(\mathbf{k g})\end{array}$ & $\begin{array}{c}\text { Course } \\
\text { aggregate }\end{array}$ & $\begin{array}{c}\text { Fine } \\
\text { aggregate }\end{array}$ \\
\hline Mix.1 & 0.64 & 280 & 180 & 960 & 935 \\
Mix.2 & 0.76 & 250 & 190 & 975 & 960 \\
\hline
\end{tabular}




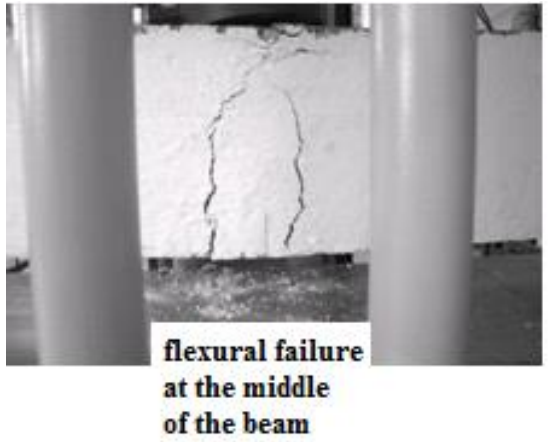

(a)

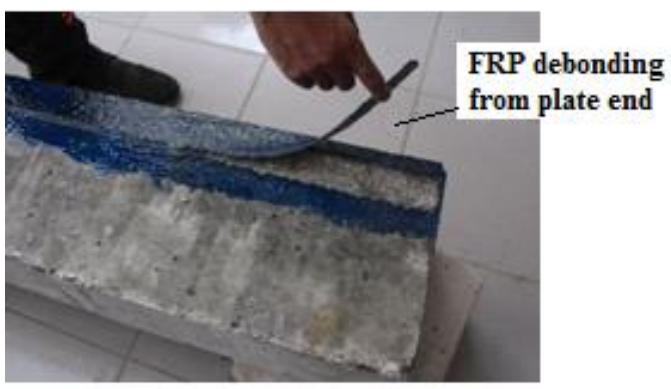

(c)

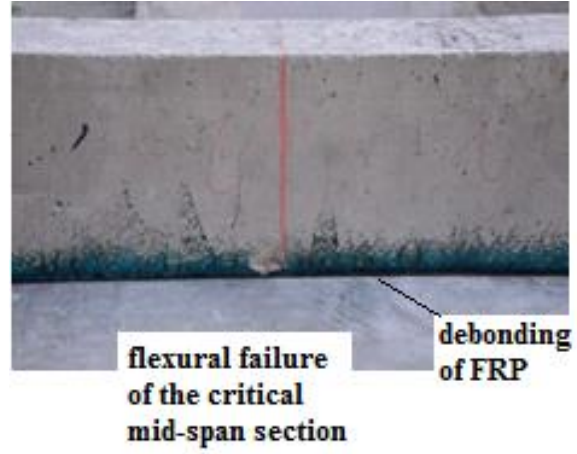

(b)

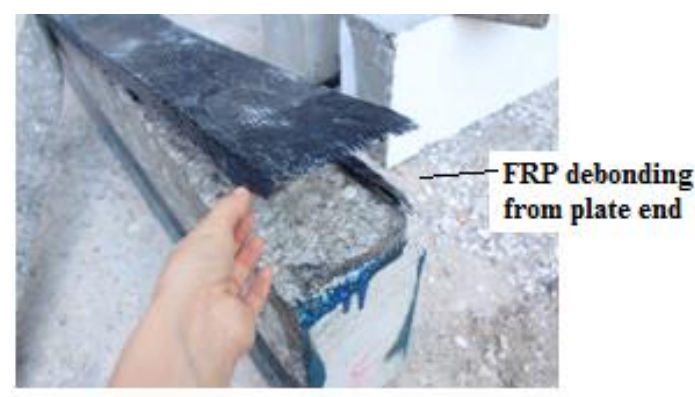

(d)

Fig. 6 Failure modes of tested first series of beams: (a) flexural failure of control beam (1-CB), (b) flexural failure of the critical mid-span section (1-SB1), (c) FRP debonding from plate end (1-SB2), (d) FRP debonding from plate end and flexure-shear cracking (1-SB3)

For the beam 1-SB1 in Fig. 6 (b), the appearance of cracks is significantly delayed and the ultimate failure was occurred by CFRP rupture at an ultimate load of $100.98 \mathrm{kN}$ in flexural mode with a mid-span deflection of $7.43 \mathrm{~mm}$. The ultimate load of 1-SB1 was measured as 2.17 times greater than the failure load of 1-CB. First crack was observed at the load level of $80 \mathrm{kN}$ and large cracks are then observed for beam 1-SB1 near failure. The low value of midspan deflection, nearly one-third of the deflection of 1-CB, is an indication of the increase in the flexural rigidity due to the CFRP strengthening. The increase in the amount of total tensile reinforcement (tensile bars+CFRP sheets) leads to a much more brittle behavior limiting the flexural deformation capacity of the longitudinal bars. A long yielding plateau previously observed for the 1-CB does not exist for this beam. Similarly, an enhancement of shear strength of 1-SB1 occurs due to the increase in the rigidity of the beam. The failure mode of the beam is observed as the intermediate crack induced debonding in Fig.5.

Beam 1-SB2 failed at an ultimate load of $118.24 \mathrm{kN}$ with a mid-span deflection of $10.60 \mathrm{~mm}$ as can be seen in Fig. 7. First crack was observed at the load level of $104 \mathrm{kN}$. Strengthened beam 1-SB3 failed at an ultimate load of $123.05 \mathrm{kN}$ with a mid-span deflection of $11.52 \mathrm{~mm}$. First crack was observed at the load level of $120 \mathrm{kN}$. The ultimate loads of 1-SB2 and 1-SB3 were measured as 2.54 and 2.65 times greater than the failure load of 1-CB respectively. The deformation capacities of 1-SB2 and 1-SB3 were higher than beam 1-SB1. These findings point out that 1-SB2 and 1-SB3 exhibit reducing the amounts of debonding and cracking and their increased rigidities due to different wrapping schemes result higher ultimate load levels than 1-SB1. Failures of these two beams are initiated by debonding of CFRP sheets from plate end as can be seen in Fig. 6 (c) and (d). Hardly visible flexural cracks are first observed near the mid-span of 1-SB2 beam. Therefore, the debonding of CFRP sheets and premature failure of FRP can be delayed since greater strain values in FRP is avoided to develop due to the crack growth for these two wrapping schemes. For beam 1-SB3, soon after initial cracks were 
first observed at greater loads compared to the cracking load levels of other beams, the failure occurred by rapidly developing the flexural crack near the mid-span and debonding of CFRP sheets from both plate end and lateral surfaces. From Fig. 7, it can also be seen that the initial stiffnesses of the beams strengthened with CFRP are getting increased due to the amount of wrapping. And also they have much higher load carrying capacity in comparison to the control beam.

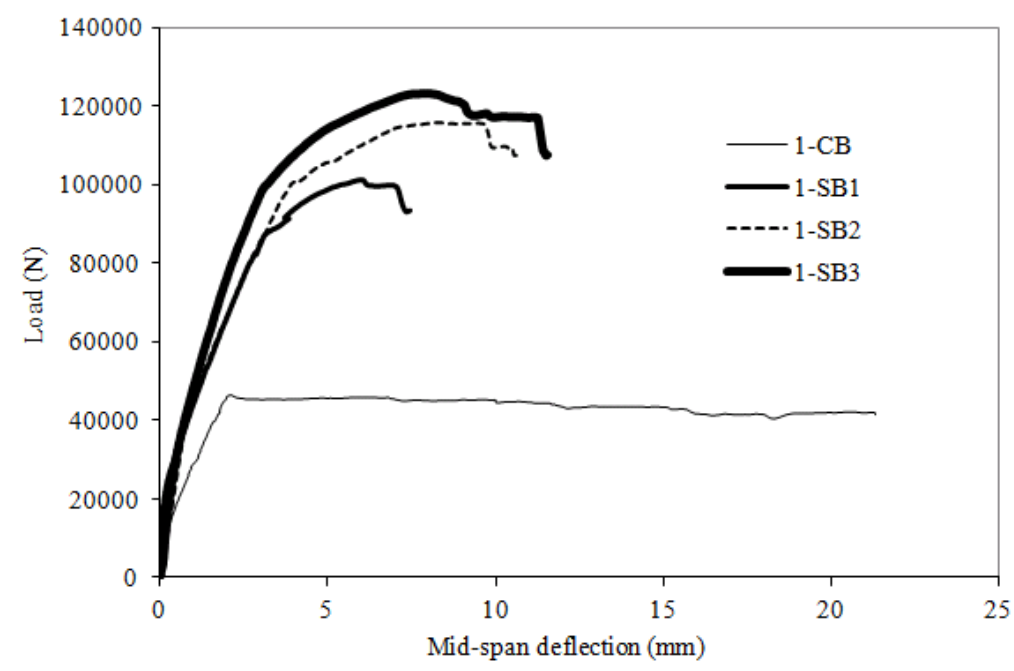

Fig. 7 Load versus mid-span deflection curves of first series of beams

Table 5 Experimental results and calculations of first series of beams

\begin{tabular}{ccccc}
\hline Specimen & $\begin{array}{c}\text { Ultimate load (kN) } \\
\text { (experimental) }\end{array}$ & $\begin{array}{c}\text { Mid-span deflection } \\
(\mathbf{m m})\end{array}$ & $\begin{array}{c}\text { Ultimate load (kN) } \\
\text { (allowable tensile } \\
\text { strain limitation) } \\
(\text { AC C440.2R-08) }\end{array}$ & $\begin{array}{c}\text { Ultimate load (kN) } \\
\text { (without any strain } \\
\text { limitation) }\end{array}$ \\
\hline 1-CB & 46.5 & 21.29 & - & 68.39 \\
1-SB1 & 100.98 & 7.43 & 110.83 & 116.79 \\
1-SB2 & 118.24 & 10.60 & 110.83 & 116.79 \\
1-SB3 & 123.05 & 11.52 & 110.83 & 116.79 \\
\hline
\end{tabular}

\subsection{Second Series of Beams (2-CB, 2-SB1, 2-SB2)}

The compressive strength of second concrete mix was determined as 6.8 MPa. Experimentally measured ultimate loads and mid deflections of the second series of beams are given in Table 6. Control beam 2-CB failed by crushing of compressive concrete at a mid-span deflection of $12.02 \mathrm{~mm}$. First crack was observed at the load level of $22 \mathrm{kN}$ which is nearly half of the cracking load of 1-CB. The large flexural and shear-flexural cracks were finally observed up to the failure as shown in Fig. 8(a). During the placement of concrete, segregation of concrete probably occurred at the beam compressive regions and therefore 1-CB fails a lower load level than the 2-CB. 


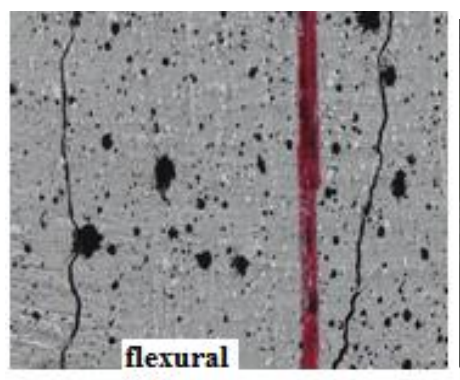

failure

(a)

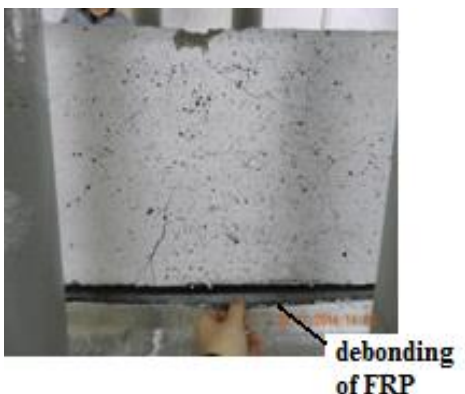

(b)

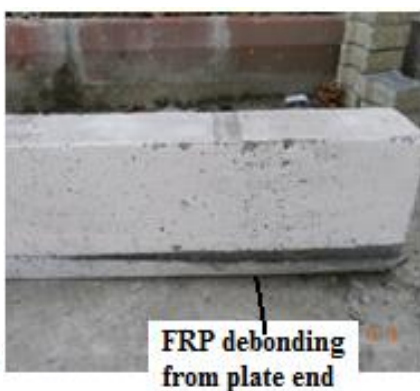

(c)

Fig. 8 Failure modes of tested second series of beams: (a) flexural failure of control beam (2-CB), (b) flexural failure of the critical mid-span section (2-SB1), (c) FRP debonding from plate end (2-SB2)

The first strengthened beam 2-SB1 failed at an ultimate load of $64.15 \mathrm{kN}$ with concrete crushing and intermediate crack induced debonding with a mid-span deflection of $8.58 \mathrm{~mm}$ as can be seen in Fig. 9. First crack was observed at the load level of $37 \mathrm{kN}$. Cracking and ultimate loads of 2-SB1 were much lower than the beam 1-SB1 as expected. The beam 2-SB2 failed at an ultimate load of $74.55 \mathrm{kN}$ with a mid-span deflection of $8.03 \mathrm{~mm}$. First crack was observed at the load level of $40 \mathrm{kN}$. Failure of this beam was finalized by both intermediate crack induced debonding and FRP-debonding from plate end. Mid-span deflections of the two strengthened beams were nearly the same although they have different amounts of CFRP sheets.

As can be seen in the Fig. 9 the increase in the ultimate load level of second series of beams is generally below the $25 \%$ of the load carrying capacity of control beam. The main factor in the slight improvement of their flexural performance appears to be highly associated with the low bond strength depending on the compressive strength of $6.8 \mathrm{MPa}$. Strengthened beams with low strength concrete $\left(f_{c} \leq 10 \mathrm{MPa}\right)$ is not very suitable for strengthening purposes inducing large amounts of debonding and cracking as expected. Therefore, there is no need to test a SB3 beam for the second series of beams because it will provide slightly better performance than the other two strengthened beams with a much greater cost. Bond characteristics of FRP techniques and the flexural performance of the strengthened beams can only be efficiently improved by increasing the quality and the compressive strength of concrete.

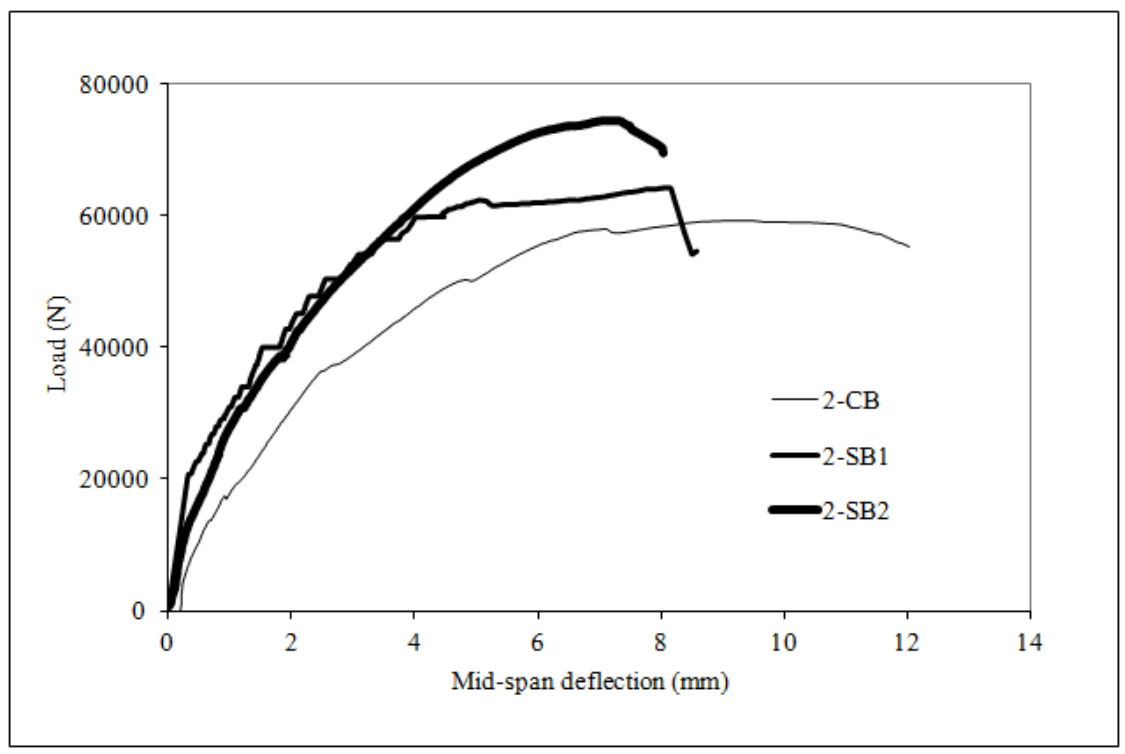

Fig. 9 Load versus mid-span deflection curves of second series of beams 
Table 6 Experimental results and calculations of second series of beams

\begin{tabular}{ccccc}
\hline Specimen & $\begin{array}{c}\text { Ultimate load }(\mathbf{k N}) \\
(\text { experimental) }\end{array}$ & $\begin{array}{c}\text { Mid-span deflection } \\
(\mathbf{m m})\end{array}$ & $\begin{array}{c}\text { Ultimate load (kN) } \\
\text { (allowable tensile } \\
\text { strain limitation) } \\
(\text { ACI440.2R-08) }\end{array}$ & $\begin{array}{c}\text { Ultimate load (kN) } \\
\text { (without any strain } \\
\text { limitation) }(\text { fib })\end{array}$ \\
\hline 2-CB & 59.22 & 12.02 & - & 52.75 \\
2 -SB1 & 64.15 & 8.59 & 70.01 & 70.01 \\
$2-S B 2$ & 74.55 & 8.03 & 70.01 & 70.01 \\
\hline
\end{tabular}

\section{Numerical Analysis and Verification of Experimental Results}

Most of the present codes and proposed analytical models employ a practical approach that tensile strain in FRP sheets should be limited to a threshold value at which intermediate crack induced debonding of FRP sheets may occur ( $\mathrm{Li}$ et al. 2013). For a given RC beam section, the concrete under compression crushes when the strain in concrete at the extreme compression fiber reaches an ultimate value of 0.003 . The following moment carrying capacity of the unstrengthened $\mathrm{RC}$ beam can be calculated as follows:

$$
M_{r l}=A_{s t} . f_{y} .\left(d-0.5 k_{1} x\right)+A_{s c} . \sigma_{s c} \cdot\left(0.5 k_{1} x-d_{2}\right)
$$

where $A_{s t}$ is the total cross sectional area of tensile reinforcement, $f_{y}$ is the yield strength of steel, $d$ is effective depth, $x$ is the depth of neutral axis, $A_{s c}$ is the area of compression reinforcement, $\sigma_{s c}$ is the stress in the compression reinforcement, and $d_{2}$ is the distance from the extreme compression top fibre to the centroid of the compression reinforcement. $\mathrm{k}_{1}$ is a coefficient that Turkish Standart TS500 adopts for the determination of the depth of equivalent stress block in reinforced concrete elements. This parameter changes from 0.70 to 0.85 depending to concrete strength.

The calculations for determining the bending moment capacity of FRP strengthened RC beam are similar to Eqn (1) except the additional capacity provided by FRP sheets.

$$
M_{r 2}=A_{s t} . f_{y} .\left(d-0.5 k_{1} x\right)+A_{s c} . \sigma_{s c} .\left(0.5 k_{1} x-d_{2}\right)+A F R P . E F R P . E F R P .\left(h-0.5 k_{1} x\right)
$$

where $A_{F R P}$ is the cross sectional area of FRP sheets, $E_{F R P}$ is elasticity modulus of FRP material, and $E F R P$ is the tensile strain in FRP sheets. The calculation steps for the ultimate moment capacity of RC beams strengthened with FRP sheets are shown in Fig. 10.
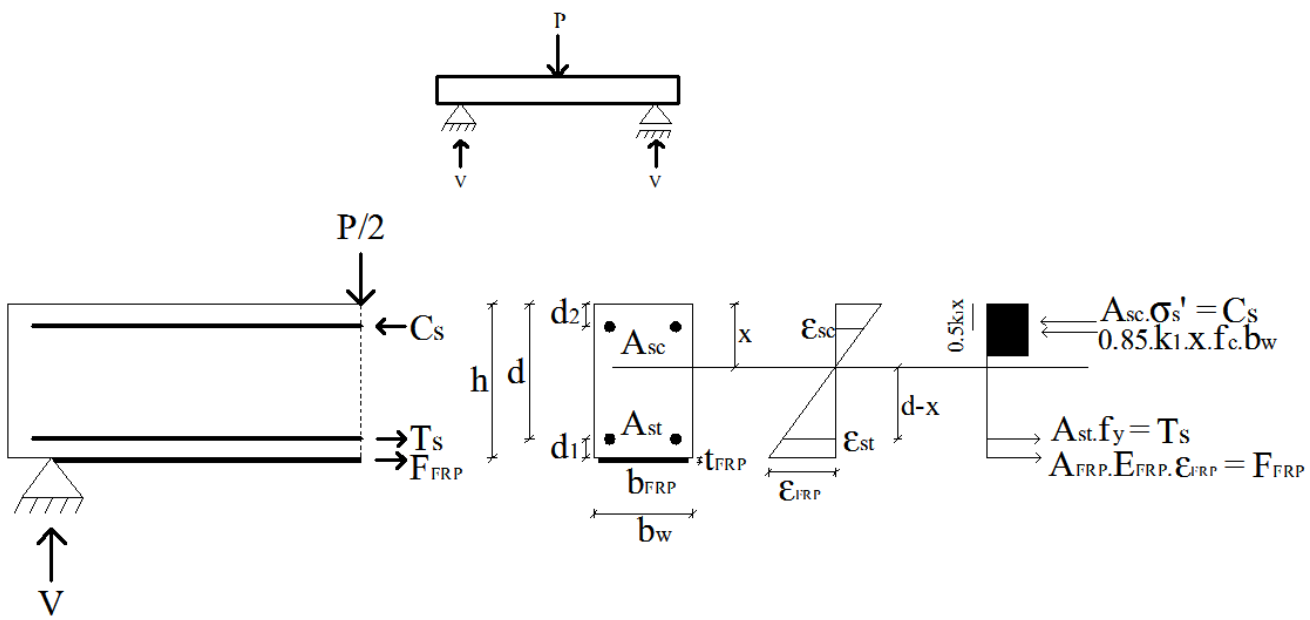

Fig. $10 \mathrm{RC}$ beam under pure bending 


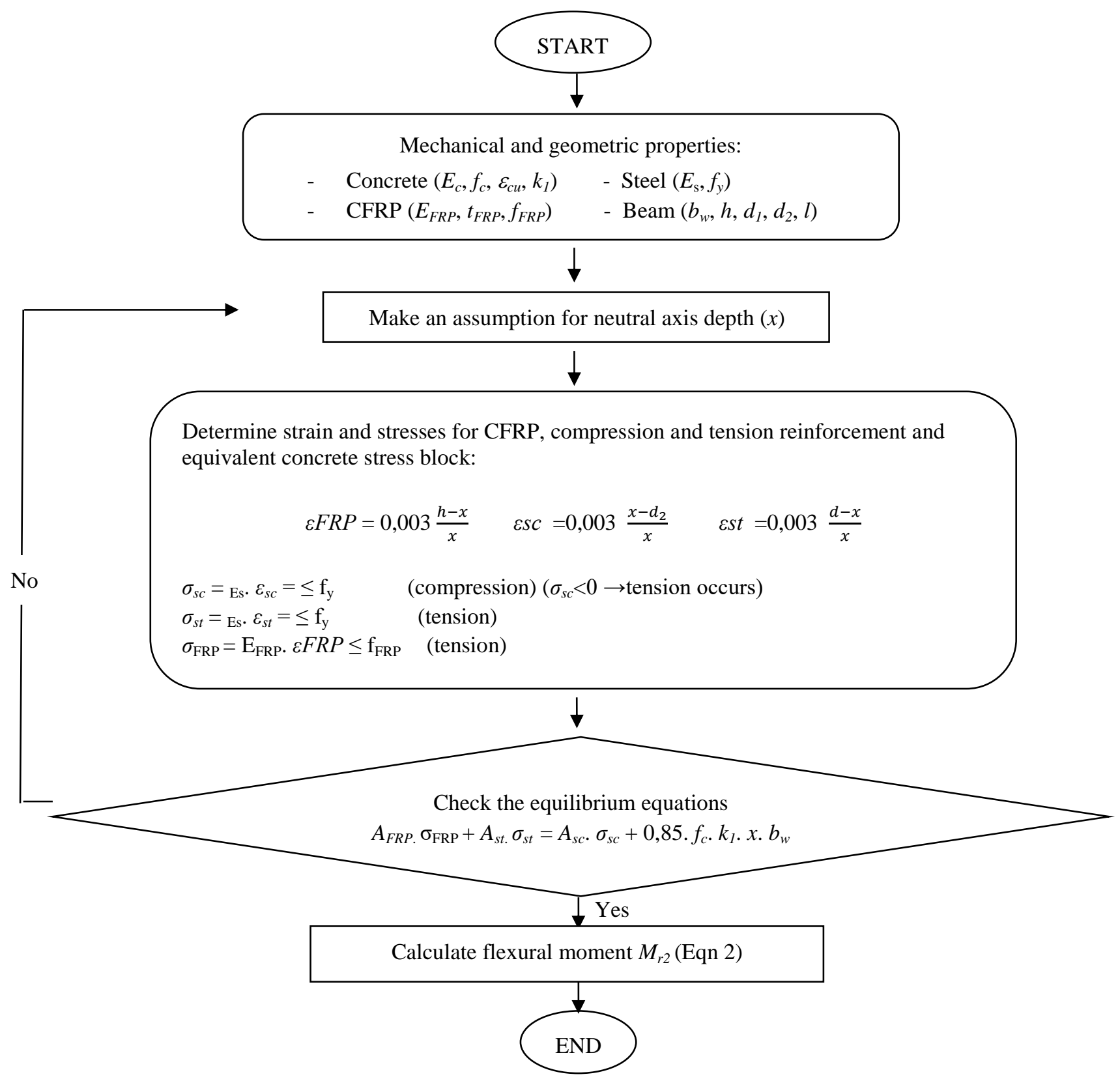

Fig. 11 Flowchart for the calculation of flexural capacity of a RC beam strengthened with FRP

The codes and guidelines prefer to use two different approaches to reflect the effects of intermediate crack induced debonding into the calculations for determining the ultimate moment capacity of a given section. First method is to use a design limitation on the CFRP tensile strain. The other one is to limit the bond shear stress. The ACI 440.2R-08 recommends a debonding equation which was based on the significant database of flexural member tests exhibiting FRP sheets debonding failure:

$$
\varepsilon_{f d}=0.41 \sqrt{f_{c}^{\prime} / n E_{f} t_{f}} \leq 0.9 \varepsilon_{f u}
$$

where $f_{c}^{\prime}$ is compressive strength of concrete; $n$ is number of FRP layers; $E_{f}$ is elasticity modulus of FRP; $t_{f}$ is thickness of FRP material, $\varepsilon_{f d}$ and $\varepsilon_{f u}$ are allowable and ultimate tensile strains in FRP laminates respectively. 
For the beam 1-SB1 the corresponding failure load is calculated as $110.83 \mathrm{kN}$ according to the guidelines of ACI-440.2R-08 and, the ultimate load is found as $116.79 \mathrm{kN}$ without using any strain limitation. The experimental failure load of this beam is $100.98 \mathrm{kN}$ and it is smaller than both of the calculated ones. The failure mode of 1-SB1 is observed as the crushing of concrete soon after intermediate crack induced debonding near the mid-span region as can be seen in Fig. 6 (b). This failure mode is the main reason for the failure load levels lower than the design values.

For the beams 1-SB2 and 1-SB3, experimental failure loads are determined as $118.24 \mathrm{kN}$ and $123.05 \mathrm{kN}$ respectively, which are higher than the calculated design load values. In the experiments, the load transfer from mid-span of beam through the support regions of the beam is mainly observed. The plate end debonding failure is an indication of this phenomenon as can be seen in Fig. 6 (c) and (d). Therefore, beams 1-SB2 and 1-SB3 can be safely designed for ACI-440.2R-08 but the wrapping scheme recommended and employed for the beam 1SB2 is a practical and economic choice.

For the second series of beams, the corresponding failure load calculated from the design formulas and the ultimate load without using any strain limitation criterion are both found as $70.01 \mathrm{kN}$. The experimental failure loads of 2-SB2 and 2-SB3 are $64.15 \mathrm{kN}$ and $74.55 \mathrm{kN}$ respectively. As expected, the failure of 2-SB1 is initiated by crushing of concrete soon after intermediate crack induced debonding shown in Fig. 8 (b). The beam 2-SB2 which have the ultimate load level higher than the design load, shows FRP debonding from plate end as can be seen in Fig. 8 (c).

\section{Conclusion}

Although debonding mechanisms are actually effective in a small fracture zone under the tensile reinforcement along the span length, the accuracy of the ultimate load prediction is significantly reduced due to the nonuniformly distributed damage. Therefore, the codes and guidelines prefer to use two different approaches for modeling the effect of intermediate crack induced debonding on the flexural behavior of RC beams strengthened with CFRP. First one is to impose a limitation on the CFRP tensile strain while the other one is to limit the bond shear stress. A delay of crack induced debonding failure can be achieved through the use of the recommended wrapping scheme covering the bottom surface of the beam and the lateral side's surfaces up to the tensile reinforcement level including the concrete cover. The enhancement of the flexural behavior of the beams strengthened with the recommended wrapping scheme is observed nearly the same with the one provided by the complete CFRP U-wrapping.

The following conclusions can be drawn from this experimental and numerical research:

1. To simulate a wide range of existing RC structures built in the 70's and 80's in Turkey, the second series of beam specimens were casted using a very low concrete strength of $6.8 \mathrm{MPa}$. A slight increase in the flexural behavior for the second series of beams has been observed. In the first series of beams with a compressive strength value of $25.7 \mathrm{MPa}$, the ultimate load capacity of strengthened beams reached almost $165 \%$ of the ultimate load of the control beam. It is obvious that the concrete strength is an important parameter for the bond shear stress for the flexural capacity of strengthened beams. As a result, if one attempts to optimize the efficiency of CFRP to upgrade the flexural performance of RC beams in terms of the ultimate load and ductility, strengthened beams should be made of higher strength of concrete preferably greater than at least $10 \mathrm{MPa}$ to provide a desired composite action.

2. The primary aim of this study is to provide theoretical predictions for the ultimate load matching the experimentally measured values employing the perfect bond assumption between concrete and FRP. For this purpose, bonding of FRP sheets to bottom surface and 
lateral side's surfaces of $50 \mathrm{~mm}$ height up to the tensile reinforcement level including the concrete cover is recommended to the beams in order to reduce the probability of crack induced debonding. Here, $50 \mathrm{~mm}$ indicates a specified length greater than the distance between the bottom surface of the beam and top surface of the tensile reinforcement. This specified length can be simply defined by adding the maximum aggregate size of the concrete mix to the distance between the bottom surface and the centroid of the longitudinal reinforcement.

3. The failure loads of the strengthened beams using the recommended wrapping scheme are found as agreed with the design loads calculated with ACI-440.2R-08. 1-SB2 and 2-SB2 beams have the ultimate loads higher than the design loads. 1-SB2 has an ultimate load capacity approximately $6.7 \%$ higher than the design load with allowable tensile strain limitation and $1.2 \%$ higher than the design load without any strain limitation. 2-SB2 has an ultimate load capacity approximately $6.5 \%$ higher than the calculated design load. The calculated and experimentally measured values of ultimate loads match for the beams strengthened with recommended wrapping scheme. The beam with U-wrapping 1-SB3 has also higher flexural capacity than the calculated one. 1-SB3 has an ultimate load capacity approximately $11 \%$ higher than the design load with allowable tensile strain limitation and $5.4 \%$ higher than the design load without any strain limitation.

4. The ultimate loads of SB1 beams with CFRP sheet on bottom surface are measured approximately $10 \%$ below the calculated design load. Therefore, bonding FRP sheets to only bottom surfaces will not guarantee to provide the design capacity calculated with ACI440.2R-08. The second wrapping scheme SB2 is more effective than SB1 and more economical than CFRP U-wrapping (SB3). There is no need to improve the existing design method or to use complicated and indefinite bond models for the determination of the ultimate loading capacity of the strengthened beam if one employs the recommended practical wrapping scheme.

Acknowledgements: This work was supported by Çanakkale Onsekiz Mart University The Scientific Research Coordination Unit, Project Number: FBA-2014-185.

\section{References}

ACI 318-11, 2011. Building Code Requirements for Structural Concrete and Commentary. ACI Committee 318. ISBN: 9780870317446.

ACI 440.2R-08, 2008. Guide for the Design and Construction of Externally Bonded FRP Systems for Strengthening Concrete Structures. ISBN: 9780870312854 (2008).

Aram M.R., Czaderski C., Motavalli M., 2008. Debonding Failure Modes of Flexural FRPStrengthened RC Beams. Composites Part B: Engineering. 39(5), 826-841.

Badawi M., Soudki K., 2009. Flexural strengthening of RC beams with prestressed NSM CFRP rods - Experimental and analytical investigation. Construction and Building Materials. 23(10), 3292-3300.

Baggio D.F., 2013. Effect of FRP Anchors on the FRP Rehabilitation of Shear Critical RC Beams and Flexure Critical RC Slabs. Master of Applied Science Thesis University of Waterloo. Ontario Canada.

Baggio D., Soudki K., Noël M., 2014. Strengthening of shear critical RC beams with various 
FRP systems. Construction and Building Materials. 66, 634-644.

Barros J.A.O., Costa I.G., Ventura-Gouveia, A., 2011. CFRP Flexural and Shear Strengthening Technique for RC Beams: Experimental and Numerical Research. Advances in Structural Engineering. 14(3), 551-571.

Büyüköztürk O., Yu, T.Y., 2006. Understanding and Assessment of Debonding Failures in FRP-Concrete Systems. Seventh International Congress on Advances in Civil Engineering. October 11-13. Y1ld1z Technical University Istanbul Turkey.

Campione G., Mangiavillano M.L., 2008. Fibrous reinforced concrete beams in flexure: Experimental investigation, analytical modelling and design considerations. Engineering Structures. 30(11), 2970-2980.

Fayyadh M.M., Razak H.A., 2014. Analytical and experimental study on repair effectiveness of CFRP sheets for RC beams. Journal of Civil Engineering and Management. 20(1), 21-31.

fib, 2001. The International Federation for Structural Concrete (Fédération internationale du béton). Externally bonded FRP reinforcement for RC structures. fib Bulletin 14.

Gunes O., 2004. A fracture-based approach to understanding debonding in FRP bonded structural members. PhD Thesis Department of Civil and Environmental Engineering. Massachusetts Institute of Technology. Cambridge MA.

ISIS, 2001. Strengthening reinforced concrete structures with externally bonded fiber reinforced polymers. The Canadian network of centers of excellence on intelligent sensing for innovative structures.

JSCE, 2001. Recommendations for upgrading of concrete structures with use of continuous fiber sheets, Japan.

Kim Y.J., 2014. Moment-Shear Interaction Mechanism for Carbon Fiber-Reinforced Polymer Strengthened Reinforced Concrete Beams in Flexure. ACI Structural Journal Technical Paper. 111(4), 967-975.

Li G., Zhang A., Guo Y., 2013. Debonding-Related Strain Limits for Externally Bonded FRP Sheets in Flexurally Strengthened Reinforced Concrete Beams. The Open Civil Engineering Journal. 7, 58-67.

Li G., Zhang A., Jin W., 2014. Effect of Shear Resistance on Flexural Debonding LoadCarrying Capacity of RC Beams Strengthened with Externally Bonded FRP Composites. Polymers 2014. 6(5), 1366-1380.

Mitolidis G.J., Salonikios T.N., Kappos A.J., 2012. Tests on RC Beams Strengthened at the Span with Externally Bonded Polymers Reinforced with Carbon or Steel Fibers. Journal of Composites for Construction. 16(5), 551-562.

Mostofinejad D., Kashani A.T., 2013. Experimental study on effect of EBR and EBROG methods on debonding of FRP sheets used for shear strengthening of RC beams. 
Composites Part B: Engineering. 45(1), 1704-1713.

Neagoe C.A., 2012. Experimental Study Regarding the Flexural Behavior of RC Beams Retrofitted with Unanchored CFRP Plates. Mathematical Modeling in Civil Engineering. 4, 149.

Nigro E., Di Ludovico, M., Bilotta, A., 2008. FRP-Concrete Debonding: Experimental Tests Under Cyclic Actions. The 14th World Conference on Earthquake Engineering. October 12-17. Beijing China.

SIA166, 2003. Klebebewehrungen (Externally bonded reinforcement). Schweizerischer Ingenieur und Architektenverein SIA.

Teng J.G., Chen J.F., 2007. Debonding Failures of RC Beams Strengthened with Externally Bonded FRP Reinforcement: Behavior and Modelling. Asia-Pasific Conference on FRP in Structures. 33-42.

TR55, 2004. Design guidance for strengthening concrete structures using fibre composite materials. Technical report no. 55 of the Concrete Society UK. 2nd edition.

TS500, 2000. Turkish Standard. Requirements for design and construction of reinforced concrete structures.

Ye L.P., Lu X.Z., Chen J.F., 2005. Design Proposals for the Debonding Strengths of FRP Strengthened RC Beams in the Chinese Design Code. Proceedings of International Symposium on Bond Behavior of FRP in Structures. December 7-9. Hong Kong China. 